\title{
Issues of Construction Health and Safety in Developing Countries: A Case of Jordan
}

Suhair Zaid Alkilani, (University of Technology Sydney, Australia)

Julie Jupp, (University of Technology Sydney, Australia)

Anil Sawhney, (Indian Institute of Technology, India)

\begin{abstract}
The construction industry is widely regarded as one of the most significant in terms of its impact on health and safety (H\&S). Recent studies suggest that in developing countries $\mathrm{H} \& \mathrm{~S}$ awareness and performance is low. In this paper, the current state of Jordan's on site construction H\&S is explored using a two-part investigation. The first part introduces the area of research in a literature based study of on-site safety. The second part presents the findings of a case study on the Jordanian construction industry and its H\&S practices. Primary data was collected from field visits, expert interviews and semi-structured questionnaires. Supporting secondary data was collected from archival studies and related research literature. The findings highlight a lack of government commitment exemplified by regulation, policy and legal constraints that limit the operational efficiency of government departments responsible for H\&S management, thus hindering the development of good $\mathrm{H} \& \mathrm{~S}$ practice. Research results also highlight the key constraints of good H\&S practice from the perspective of construction contractors. The study concludes with a discussion of potential solutions to improve H\&S performance on construction sites in Jordan.
\end{abstract}

Keywords: Health and safety, Construction industry performance, Management processes, Procurement methods, Jordan

\section{Introduction}

The construction industry is widely recognized as being both economically and socially important (Ofori 2011). Yet the industry is also considered to be the most hazardous (Larcher and Sohail 1999, Jannadi and Bu-Khamsin 2002, Konkolewsky 2004, Charles 2007, Hamalainen et al. 2007, Farooqui et al. 2008). Global estimates by the International Labor Organization (ILO) show that occupational health and safety (OHS) problems in the construction industry are more extensive than previously recorded (Larcher and Sohail 1999, Hamalainen et al. 2007, Murie 2007). Globally, poor performance in the industry accounts for more than 100,000 fatalities annually, equating to approximately $30-40 \%$ of the world's work related fatal injuries (Jill and John 2010, ILO. 2010).

Whilst the governments and industry bodies of developed countries acknowledge that the construction industry's undesirable accident record must be improved (Chileshe and Dzisi 2012), with many advocating the adoption of a zero accident policy (Jill and John 2010), poor safety records continue to hinder performance improvement. This is particularly evident in developing countries where a dearth of reliable information on occupational accidents exists due to the absence of proper recording and notification systems, coupled with low construction H\&S awareness (Fang et al. 2004, Paivi et al. 2006, Hamalainen et al. 2007, Chiocha et al. 2011). In a comparative study of a developing country, South Africa, with a developed country, Singapore, Toe et al. (2008) illustrate the disparities in construction H\&S performance. The construction sectors of developing countries are typically dominated by contractors that can be classified as small and medium sized enterprises (SMEs) which operate mainly within domestic markets (Kheni et al. 2006). As previous studies show these contractors give little attention to H\&S issues (Weil 2001, Petrovoc-Lazarevic and Perry 2004), which results in a significant number of accidents and health problems (Weil 2001). 
Numerous factors have been identified that could influence $\mathrm{H} \& \mathrm{~S}$ management of construction sites in developing countries (Toole 2002, Gibb and Bust 2006, Chiocha et al. 2011, Alkilani et al. 2012b); they include: poor infrastructure, lack of appropriate H\&S regulation, legislation and laws, low literacy levels among laborers, lack of proper recording and notification systems, competitive tendering, extreme weather conditions, and corruption (Kartam et al. 2000, Gibb and Bust 2006, Alkilani et al. 2012b).

As in many other developing economies, Jordan's society and economy have suffered human and financial losses as a result of poor $\mathrm{H} \& \mathrm{~S}$ management in the construction industry (El-Mashaleh et al. 2010). The construction sector is an integral part of Jordan's infrastructure development and significantly boosts its economy (Alkilani et al. 2012b). The sector accounts for between 5 and $8.3 \%$ of GDP (during the period of 1998-2012). The structure of the sector is tied to the Ministry of Public Works and Housing (MPWH) and together with the Jordanian Construction Contractors Association (JCCA) contractors are registered and classified according to five grade categories. Grading is based on a company's registered capital, financial status and qualifications (JDOS 2010). The classification system ranges from 'Grade 1', which designates the largest and most experienced contractors, to 'Grade 5', designating the smallest (JCCA 2012). The sector is also highly dependent upon manual labor, of which a high proportion is comprised of unskilled foreign workers (mostly Egyptian), most with minimal education who work for low wages (MOL 2010). Annual reports published by the Ministry of Labor and Social Security Department (between 2006-2010) show that the sector is associated with a disproportionately high number of job-related accidents and diseases compared to other industries, accounting for $10.5 \%$ of all workplace accidents (El-Mashaleh et al. 2010).

This study presents a literature review and findings from investigative interviews with government institutions and local contractors on the issues affecting H\&S performance in developing countries and specifically in Jordan. The study aims to:

1- Review H\&S initiatives undertaken globally to improve performance in the construction industry.

2- Investigate existing H\&S procedures, regulations, polices, and practices in Jordan's construction industry.

3- Identify the constraints and challenges for good H\&S practices in Jordan's construction industry.

4- Suggest possible solutions for government and industry bodies to improve H\&S performance in Jordan.

\section{Methodology}

Data for the study was collected in three stages. Stage one comprised a review of H\&S literature in the construction industry with a focus on internationally recognized research and initiatives that address H\&S via performance improvement measures, management processes and procurement methods. The research publications surveyed included studies of construction H\&S from both developed and developing economies. The literature was then analyzed to create a framework that informed the design of a case study of Jordan and helped form the semi-structured interview questionnaires used to gather primary data in Stage two.

Stage two of the research design therefore encompassed data collection. The case study focused on conducting semi-structured interviews with 27 experts representing a cross section of industry voices. Classifications of case study's interviewees fall into two main categories, namely: (1) Government experts - including the General Directors and H\&S officers from the MPWH's Government Tendering Department as well as the Ministry of Labor's Health and Safety Department; and (2) Industry experts - including the managing

Alkilani, S Z et al (2013) 'Issues of construction health and safety in developing countries: a case of Jordan', Australasian Journal of Construction Economics and Building, 13 (3) 141-156 
directors, owners, project and technical managers, and safety engineers of 23 construction contractor firms. Interviewee participants from the Government Tendering Department were targeted as this body is responsible for providing transparent government procurement processes, managing tender for public projects, and developing the legislation that governs those tenders. Jordan's Ministry of Labor is responsible for enforcing H\&S regulations across all industries (MOL 2010). These two government departments were selected for interview due to their unique perspective, role, influence and overview of $\mathrm{H} \& \mathrm{~S}$ and related construction issues. The 23 contractor firms were selected based on their grading by the MPWH and JCCA, so that the sample provided a good representation of all grades (i.e., Grade 1 through to 5 contractors). The sample comprised of: four Grade 1 firms, seven Grade 2 firms, seven Grade 3 firms, three Grade 4 firms, and two Grade 5 firms. The contractors selected therefore varied considerably in relation to their registered capital, financial status, qualifications and experience. Additional characteristics about each firm are shown in Table 1. Due to differences between the government and industry roles, two semi-structured interview questionnaires were designed to elicit responses from government and industry representatives. Interviews with government representatives comprised questions concerning current procurement methods used in selecting contractors and executing projects, methods for collecting $\mathrm{H} \& \mathrm{~S}$ data, and the availability of $\mathrm{H} \& \mathrm{~S}$ performance measures. The contractors' interview questions consisted of two main parts, including: general information about the firm, and current H\&S administration and practices. Specific questions were asked based on each contractor's safety policy, H\&S management processes and incident and injury reporting procedures, safety measures and personal protection equipment (PPE), employee H\&S training, and insurance systems.

In Stage three, data collected from the literature review, local research and interviews were used to identify a list of barriers to the implementation of good H\&S practices in Jordan. This list was forwarded to the same group of participants interviewed in Stage two via office visits and email correspondence, after which each participant was asked to rank each barrier identified using 5-point Likert scale, where 1 is the least relevant and 5 is the most relevant. The results and analysis of the data from all three stages of research are presented in the following sections.

\section{Literature Review: Currents of Change in Construction Health and Safety}

As a reflection of the range of $\mathrm{H} \& \mathrm{~S}$ problems in construction a large body of research exists which reveal key factors driving better H\&S performance. Most significantly, safety regulations are often cited as crucial to reducing construction work accidents (Kartam et al. 2000). Organizational safety policies have also been identified as a major driver (Hinze and Wilson 2000). The Construction Industry Institute (CII) ranked safety training and safety incentives and penalties as two of five high-impact zero accident techniques targeted at improving safety performance at the project level (Hinze \& Wilson 2000). Jaselskis et al. (1996) recommended increasing the number of formal safety meetings with supervisors, and Chi et al. (2005) argued that safety equipment is crucial to minimizing and preventing site accidents. Hinze \& Wilson (2000) state that safety inspections and jobsite visits are required to improve safety performance. As worker attitude towards safety is considered as a root cause of accidents, Abdelhamid \& Everett (2000) also reported that educating and training workers is an important factor that drives better H\&S performance.

Many countries have established and released their own safety programs and systems of performance measurement and management. Key performance indicators (KPIs) and safety factors that pertain to H\&S have been identified and enforced throughout construction industries of the developed world (Scotney 2000, John and Anthony 2001). From a procurement perspective, safety is also reported as an essential part of recommended regulatory frameworks (Farooqui et al. 2008).

Alkilani, S Z et al (2013) 'Issues of construction health and safety in developing countries: a case of Jordan', Australasian Journal of Construction Economics and Building, 13 (3) 141-156 


\section{Safety Performance Measures and Management}

Several safety performance measures have been developed to describe on site H\&S performance (Idoro 2011), and to evaluate a firm's safety performance (Jaselskis et al. 1996). For example, the experience modification rate and OSHA's reportable incidence rate, as well as the lost workday rate and lost-time rate, have been implemented to evaluate company safety performance over a number of years (Jaselskis et al. 1996, Levitt 1976, Idoro 2011). Jaselskis et al. (1996) propose quantitative strategies for achieving better safety performance differentiating between company and project levels. Among the more significant company-related factors are upper management support, time devoted to safety issues by the company safety coordinator, meetings with field safety representatives, informal safety inspections, safety training, and company safety expenditures. At the project level, several factors are identified by Jaselskis et al. (1996) namely: increasing project manager experience levels, reducing project team turnover, reducing worker penalties, and increasing budget allocation to safety awards.

Examples of safety performance measurement initiatives in developed countries are numerous. In the US, the CII released the Zero Injury Technique (Hinze and Wilson 2000), where five high-impact zero accident techniques have been identified. In the UK, the audit program has been implemented as a safety competition, whereby the results are then used for benchmarking a company's H\&S management system (Colin 1999). In the UK the Health and Safety Executive have developed a tool to measure H\&S performance and improvement over time within any sector which is based on H\&S KPIs (Scotney 2000, Charles et al. 2007). In Australia, the Health and Safety Continuous Improvement Matrix, developed by the Construction Industry Development Agency in 1995, is used as a benchmarking system for the comparison of OHS performance across the Australian construction industry. The system allows the grading of a company's OHS between zero and five against $17 \mathrm{OHS}$ system elements that are set out on the matrix (John and Anthony 2001).

\section{Procurement}

Traditionally, the criteria for contractor selection in the construction industries of developing countries are generally focused on tender cost (Bowen et al. 2002, Jill and John 2010). It is common practice for contractors to reduce their cost to win tenders, where cuts in $\mathrm{H} \& \mathrm{~S}$ management processes are one of the first items to face cost cutting exercises, and as a result OHS can suffer (Jill and John 2010). In a joint publication by the UK's Institute of Civil Engineers (ICE) and Engineers Against Poverty (EAP) it was reported that the current procurement routes hinder the improvement of H\&S practices (Jill and John 2010). Hinze (1988) (cited in John and Anthony 2001) found that injury rates tend to be higher on those projects that were competitively bid. In their briefing note, the ICE and EAP argue that there are two main reasons why H\&S should be considered a serious issue during the procurement of construction services and works. Firstly, to ensure that the responsibilities to maintain a safer site are set out in the procurement terms, enabling H\&S issues related to the project and services to be taken seriously by all participating parties. Secondly, that the procurement process, contract terms and conditions be seen as complementary mechanisms for ensuring compliance with existing legislation and/or terms and conditions of project finance (Jill and John 2010).

A number of countries are reforming their procurement systems with the aim to raise the standard of OHS on construction projects. For example, as a part of China's National Economic Reform, the construction industry is moving towards competitive procurement systems (Charles et al. 2007). In the UK, the traditional lowest price contractor selection process is shifting toward the use of multiple selection criteria and a best-value contractor selection framework (Charles et al. 2007). New Zealand is also following these trends, where the Department of Labor recently published "A Principals Guide to Contracting to Meet the

Alkilani, S Z et al (2013) 'Issues of construction health and safety in developing countries: a case of Jordan', Australasian Journal of Construction Economics and Building, 13 (3) 141-156 
Health and Safety in Employment Act 1992". The guidance sets out a broad process for building H\&S into construction contracts (DOL 2010).

\section{Agencies}

To ensure that on site worker H\&S standards are maintained, a number of countries have established agencies with varying objectives and geopolitical structures. Three types of agency can be distinguished: government, independent and joint; with each potentially having three levels, namely international, regional and national. Example agencies range from those that aim to shape polices and produce standards covering the entire spectrum of work-related H\&S issues, such as the International Labour Organization (ILO 1992), to agencies that support government H\&S strategy by providing education and certification. For example the UK's Health and Safety Executive (Scotney 2000) and National Examination Board in Occupational Safety and Health (NEBOSH 2013), the US's National Institute for Occupational Safety and Health (NIOSH 2012), and National Occupational Health and Safety Commission. Joint agencies bring together government and industry initiatives, e.g. the European Agency for Safety and Health at Work (EASHW 2013). Agencies responsible for enforcing $\mathrm{H} \& \mathrm{~S}$ in construction are predominantly joint initiatives.

In developing countries by contrast H\&S agencies are often public bodies linked to government ministries and social security departments (Agyem-Bediako 2007). Thus, their construction sectors are predominantly characterized by top-down strategies rather than joint or bottom-up industry driven initiatives and thereby lack independence. Poor inter-agency cooperation and communication also persists in construction sectors of developing countries. This study confirms that this is the case in Jordan, where the main bodies responsible for H\&S are the MPWH and the Ministry of Labour.

\section{Findings - Part 1: Status of H\&S Performance in Jordan}

Research on construction H\&S in developing countries provide ample evidence of lapses in H\&S regulations and standards, management practice and awareness (Kheni et al. 2006). Many of these findings are confirmed in this case study. This section reports the findings from a two-part semi-structured interview and questionnaire process. Significantly, findings from interviews with key experts from the two government bodies responsible for $\mathrm{H} \& \mathrm{~S}$ revealed a lack of regulations and standards specific to the construction industry. Further, the findings from the 23 contractor interviews reflect problems and shortcomings resulting from the dominance of SME contractors in Jordan. The practice-based issues identified echo existing research on H\&S performance in other developing countries, confirming that SME dominance is related to more significant numbers of accidents and injuries (Gibb and Bust 2006). In Jordan the economy depends almost entirely on SME contractors to help drive productivity, where about $98 \%$ of all businesses are classified as SMEs (JEDCO 2011). Furthermore contactors, and in particular SME contactors - classified by the JCCA as Grade 3,4 and 5 - failed to provide minimal requirements to achieve better safety performance as shown in Table 1. The case study highlights that although a few contactors have adopted effective H\&S practices the majority rely solely on the specification of H\&S procedures and standards in contracts but had no monitoring practices onsite.

Detailed findings from this study are presented in the following sections, where three issues are identified as the main factors that influence H\&S practice and characterize the status of construction H\&S in Jordan, namely; (1) Government institutions responsible for health and safety, (2) Procurement methods, and (3) Contractor attitudes. The constraints surrounding the implementation of better H\&S practices in Jordan's construction industry as identified by the respondents are described.

Alkilani, S Z et al (2013) 'Issues of construction health and safety in developing countries: a case of Jordan', Australasian Journal of Construction Economics and Building, 13 (3) 141-156 


\title{
Government Institutions
}

As a part of the Ministry of Labor, the Department of H\&S ensures all workplaces maintain minimum standards of H\&S. Apart from undertaking workplace inspections; the Department is responsible for administrating the labor code, Law Act No. 8 of 1996, as well as Sections 78 to 85 of the H\&S standards describing workplace H\&S regulations. Jordan's current H\&S standards were adopted from the US' OSHA standards. The Social Security Department is responsible for publishing statistics about work injuries, accidents, and deaths. These statistics are published annually by the Ministry of Labor. Whilst the reported statistics cover work-related accidents, injuries and fatalities for all industries, there is no specific statistics for individual industries. Consequently there is a lack of detailed information on construction industry accidents, injuries and fatalities. The interview participant from the Department of Health and Safety reported that:

\begin{abstract}
"There is no specific data for the number of accidents in the construction industry; this is one of the major weaknesses in our database and statistics which we are currently working on. However, we need government support and in particular the MPWH helping with this, as they should put pressure on the industry i.e. the contractors to regularly report accidents". (H\&S Officer, Department of Health and Safety, Ministry of Labor)
\end{abstract}

The H\&S official also stated: "These statistics represent only the number of accidents that are reported by the owner or contractor, for the purposes of social security cover and compensation, and does not represent the actual number of accidents in the construction workplace; it even doesn't comprise $10 \%$ of the real accident number". (H\&S Officer, Department of Health and Safety, Ministry of Labor)

The Ministry of Labor's Department of H\&S issue labor certificates to contractors bidding for jobs to certify compliance with all labor laws. Another interviewee from the Government Tendering Department reported: "It is however difficult to assess whether a contractor issued with a labor certificate continues to comply with working conditions outlined in Labor Law 1996". (Officer, Government Tendering Department, MPWH)

Furthermore, the Department of H\&S deals directly with onsite construction accidents, after being notified of accidents via the Police Department (where accidents must be reported). The Department of H\&S is then responsible for contacting the Department of Social Security where additional investigations are conducted for insurance purposes. In undertaking accident reports and other regular H\&S procedures, the Ministry of Labor hires H\&S engineers and inspectors who are responsible for conducting site inspections. In this regard, the H\&S Officer stated that:

\begin{abstract}
"In the process to improve H\&S performance in the construction industry we increased the number of inspectors, however it is still not enough to conduct a daily site inspection, we have 50 safety engineers and inspectors who are working throughout Jordan at the moment, I believe we need at least triple this number if not more, if daily site inspections are going to be done, which we have a lack of" (H\&S Officer, Department of Health and Safety, Ministry of Labor).
\end{abstract}

\section{Procurement Methods}

The Officer from the Government Tendering Department reported that the main procurement method used when executing public projects is the traditional lowest-price tender method. Contractors are invited to bid via tender advertisements in local newspapers and via the Government Tendering Department website. Bids are secured in a 'closed envelop' and lodged with the MPWH in a secured box. The bids are read in the presence of all bidding contractors and a committee of consultants, MPWH decision makers, and any project-

Alkilani, S Z et al (2013) 'Issues of construction health and safety in developing countries: a case of Jordan', Australasian Journal of Construction Economics and Building, 13 (3) 141-156 
related government institutions and sponsors. In most public projects the winning contractor is typically the one who presented the lowest price tender.

The 'general' and 'special' conditions for contracting in Jordan were also highlighted. General conditions are valid for government buildings and housing. In such cases, the MPWH requires, as part of the contract's general requirements, the provision of minimum H\&S requirements (adopted from the Labor Law 1996 for H\&S at work), which includes for example, onsite safety personnel and PPE for all workers. However despite these measures there is no specific safety cost disclosure required as part of the tender contract documents, and the winning contractor is not subject to monitoring processes to ensure the project complies with H\&S requirements. The Government Tendering Department interviewee highlighted these difficulties:

\begin{abstract}
"After winning the contract it's the contractor's responsibility to monitor H\&S onsite, however we are responsible for investigating accidents if they happen and if reported, we penalize the contractor for violation of H\&S requirements". (Officer, Government Tendering Department, MPWH)
\end{abstract}

In addition, the regulations were criticized by one interviewee due to their lack of detail and brevity. One H\&S manager stated:

\begin{abstract}
"Several major safety issues are not described in enough detail. For example, the specification of safety equipment, what, when and where to wear them, are not stated. This leaves such requirements to be solely judged by employers". (H\&S Officer, Department of Health and Safety, Ministry of Labor)
\end{abstract}

Special conditions are used when establishing contracts for public infrastructure projects, such as wastewater and sewage treatment plants, and highways. These projects are usually sponsored and funded by foreign international agencies such as the UN and the World Bank. Under the special conditions of public infrastructure projects, $H \& S$ is a major requirement when selecting local contractors and subcontractors. Sponsoring organizations typically require detailed safety plans, evidence of a H\&S track record, and that all bidding contractors meet H\&S prequalification requirements. In addition, project specific international $\mathrm{H} \& \mathrm{~S}$ requirements may also be specified by the foreign sponsor and any participating foreign contractor.

\title{
Attitudes of Local Construction Contractors
}

To understand the attitudes of construction contractors toward $\mathrm{H} \& \mathrm{~S}$, semi-structured interviews were conducted with managing directors, owners, project and technical managers, and safety engineers working in all classes of companies. Interview questions were divided into two parts, the first sought information about the firm's profile and size; the second sought information about safety policy, safety reports and records, safety manuals, safety measures, accidents numbers and accidents reporting systems, the use of PPEs, insurance, the role of safety management officers. The interview also included questions related to the number of accidents and their bearing on the cost of claims. However, some respondents refused to answer these questions, believing that this information was confidential and may negatively affect their company's reputation. These questions were therefore excluded from analysis. Table 1 summarizes the results.

Overall the results highlight that attitudes of Jordan's contractors towards construction site $\mathrm{H} \& \mathrm{~S}$ is poor due to lack of H\&S awareness and knowledge. Poor attitudes to H\&S were also reflected in the preference given to commercial profits over most other project objectives, with H\&S objectives being given a low priority by SMEs. One Ministry of Labor interviewee from the Department of H\&S described SME contractor attitudes as being compromised by financial considerations:

Alkilani, S Z et al (2013) 'Issues of construction health and safety in developing countries: a case of Jordan', Australasian Journal of Construction Economics and Building, 13 (3) 141-156 
"Contractors, and in particular small enterprises, want to make the maximum profits and cannot provide the required personal protective equipment for their workers. They do not have safety policies in place... and they wouldn't want to spend their time, money and resources to train their workers to a certain standard of H\&S." (H\&S Officer, Department of Health and Safety, Ministry of Labor)

\begin{tabular}{|c|c|c|c|c|c|c|c|c|c|c|c|c|}
\hline $\begin{array}{r}\text { Contactor } \\
\text { Grade }\end{array}$ & 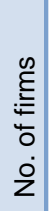 & 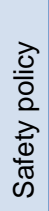 & $\begin{array}{l}\text { س } \\
\frac{0}{\alpha}\end{array}$ & 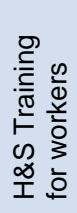 & 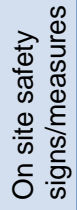 & 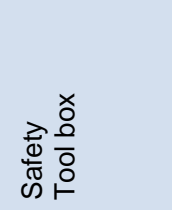 & 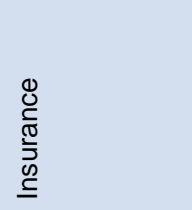 & 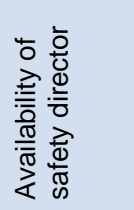 & 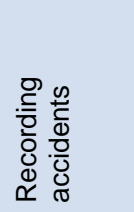 & & 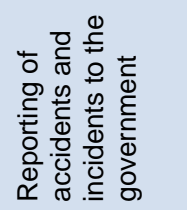 & \\
\hline Grade 1 & 4 & 4 & 4 & 3 & 4 & $\begin{array}{ll}\text { Weekly } & 2 \\
\text { Monthly } & 2 \\
\text { Occasionally } & 0\end{array}$ & $\begin{array}{lr}\text { Social security } & 4 \\
\text { Other } & 0\end{array}$ & $\begin{array}{l}\text { Full-time } 4 \\
\text { Part-time } 0\end{array}$ & $\begin{array}{l}\text { Regularly } \\
\text { Sometimes } \\
\text { Never }\end{array}$ & $\begin{array}{l}2 \\
2 \\
0\end{array}$ & $\begin{array}{l}\text { Regularly } \\
\text { Accident driven }\end{array}$ & $\begin{array}{l}0 \\
4\end{array}$ \\
\hline Grade 2 & 7 & 5 & 4 & 2 & 6 & $\begin{array}{ll}\text { Weekly } & 1 \\
\text { Monthly } & 3 \\
\text { Occasionally } & 4\end{array}$ & $\begin{array}{ll}\text { Social security } & 7 \\
\text { Other } & 0\end{array}$ & $\begin{array}{l}\text { Full-time } 4 \\
\text { Part-time } 3\end{array}$ & $\begin{array}{l}\text { Regularly } \\
\text { Sometimes } \\
\text { Never }\end{array}$ & $\begin{array}{l}2 \\
5 \\
0\end{array}$ & $\begin{array}{l}\text { Regularly } \\
\text { Accident driven }\end{array}$ & $\begin{array}{l}0 \\
7\end{array}$ \\
\hline Grade 3 & 7 & 0 & 1 & 1 & 1 & $\begin{array}{lr}\text { Weekly } & 1 \\
\text { Monthly } & 2 \\
\text { Occasionally } & 4\end{array}$ & $\begin{array}{ll}\text { Social security } & 7 \\
\text { Other } & 0\end{array}$ & $\begin{array}{l}\text { Full-time } 2 \\
\text { Part-time } 3\end{array}$ & $\begin{array}{l}\text { Regularly } \\
\text { Sometimes } \\
\text { Never }\end{array}$ & $\begin{array}{l}0 \\
2 \\
0\end{array}$ & $\begin{array}{l}\text { Regularly } \\
\text { Accident driven }\end{array}$ & $\begin{array}{l}0 \\
7\end{array}$ \\
\hline Grade 4 & 3 & 0 & 0 & 0 & 0 & $\begin{array}{ll}\text { Weekly } & 0 \\
\text { Monthly } & 1 \\
\text { Occasionally } & 2 \\
\end{array}$ & $\begin{array}{lr}\text { Social security } & 3 \\
\text { Other } & 0\end{array}$ & $\begin{array}{l}\text { Full-time } 0 \\
\text { Part-time } 1\end{array}$ & $\begin{array}{l}\text { Regularly } \\
\text { Sometimes } \\
\text { Never }\end{array}$ & $\begin{array}{l}0 \\
2 \\
1\end{array}$ & $\begin{array}{l}\text { Regularly } \\
\text { Accident driven }\end{array}$ & $\begin{array}{l}0 \\
3\end{array}$ \\
\hline Grade 5 & 2 & 0 & 0 & 0 & 0 & $\begin{array}{ll}\text { Weekly } & 0 \\
\text { Monthly } & 1 \\
\text { Occasionally } & 1\end{array}$ & $\begin{array}{ll}\text { Social security } & 2 \\
\text { Other } & 0\end{array}$ & $\begin{array}{l}\text { Full-time } 0 \\
\text { Part-time } 0\end{array}$ & $\begin{array}{l}\text { Regularly } \\
\text { sometimes } \\
\text { Never }\end{array}$ & $\begin{array}{l}0 \\
0 \\
2\end{array}$ & $\begin{array}{l}\text { Regularly } \\
\text { Accident driven }\end{array}$ & $\begin{array}{l}0 \\
2\end{array}$ \\
\hline
\end{tabular}

Table 1 Contractors' interview results

While previous research has identified organizational safety policy, safety training, safety meetings, safety equipment's, safety inspections, safety incentives and penalties as amongst the key factors driving safety performance (Jaselskis et al. 1996, Abdelhamid and Everett 2000, Hinze et al. 2000, Charles et al. 2007, El-Mashaleh et al. 2010, Jill and John 2010), the results in Table 1 reveals additional shortcomings in relation to the lack of international conventions surrounding onsite H\&S being followed by contractors in Jordan. Only nine out of the 23 companies investigated have safety policies in place, and all nine were either Grade 1 or 2 companies, i.e., large and experienced firms with high levels of registered capital, finance, and qualifications. On average $75 \%$ of the sites visited when conducting the case study provided no evidence of H\&S practices being in place, such as the posting of safety signs and safety measures, including the absence of PPEs, worker training and "tool box" safety talks. The project managers and H\&S directors interviewed reported that due to pressures from senior management and owners to complete projects on time and in budget, they did not feel able to interrupt works for H\&S talks or safety meetings. One interviewee said:
"..Panic plus rush plus safety, does not work..., [...] The owner who is the manager of the company l'm working at tells the project manager: 'as much as you save money and time...I will pay you a bonus...'. The project manager then does not care about how safe his project is... he even does not allow me to stop the work for 10 minutes each week or even each month to do training or "tool box" safety talks with the workers". (Contractor H\&S Site Officer)

Most interviewees from industry reflected these sentiments and stated that implementing $\mathrm{H} \& \mathrm{~S}$ procedures would substantially increase the cost of construction. Consequently, the cost implementation of safety procedures was not disclosed in the contractor's bid and generally only the insurance cost was considered for those items.

Alkilani, S Z et al (2013) 'Issues of construction health and safety in developing countries: a case of Jordan', Australasian Journal of Construction Economics and Building, 13 (3) 141-156 


\section{Findings - Part 2: Constraints on Construction H\&S in Jordan}

The study found that Jordan's construction industry is hindered by many challenges that adversely affect H\&S performance. These findings form a number of significant constraints or barriers to implementing good H\&S practice on construction sites and are grouped thematically into three classes as shown in Table , namely: 1) Government regulations, legislation, and policies, 2) Management commitment and involvement, and 3) Worker awareness.

\begin{tabular}{|c|c|c|c|}
\hline Main Groups of Constraints & RII & Sub-constraints Factors & RII \\
\hline \multirow{8}{*}{$\begin{array}{l}\text { Government Regulations, } \\
\text { legislations and Laws }\end{array}$} & 0.85 & & \\
\hline & & Current procurement methods and contractor selection criteria & 0.82 \\
\hline & & Lack of $\mathrm{H} \& \mathrm{~S}$ regulations for construction & 0.8 \\
\hline & & Lack of relevant accident data, statistics and information & 0.69 \\
\hline & & Current labor laws & 0.62 \\
\hline & & Insufficient insurance schemes & 0.54 \\
\hline & & Insufficient penalties schemes & 0.52 \\
\hline & & Inadequate support for innovation, research and technology & 0.4 \\
\hline \multirow{6}{*}{$\begin{array}{l}\text { Management Commitment and } \\
\text { involvement }\end{array}$} & 0.76 & & \\
\hline & & Inadequate supply of PPE for workers & 0.8 \\
\hline & & Insufficient accident recording and reporting systems & 0.72 \\
\hline & & Inadequate training and education programs & 0.66 \\
\hline & & Insufficient safety meeting time with workers & 0.64 \\
\hline & & Insufficient communication channels & 0.61 \\
\hline \multirow[t]{4}{*}{ Workers awareness } & 0.66 & & \\
\hline & & Unwilling to wear PPE & 0.86 \\
\hline & & Extensive use of foreign labor & 0.86 \\
\hline & & High percentage of uneducated/unskilled labor & 0.77 \\
\hline
\end{tabular}

Table 2 Constraints for good health and safety practice

For each group a list of underlying issues were identified from the literature review and case study interviews. Stage 3 of the study then asked participants to firstly rank the importance of the three main classes of constraints, and then rank each underlying factor using a 5Point Likert Scale, where 1 is the least important and 5 is the most. The Relative Importance Index (RII) method (Kometa et al. 1994) was used to calculate the significance of each category's rank, revealing the significance of three main classes and 15 sub-constraints shown in Table. The RII is computed as:

$\mathrm{RII}=\frac{\sum W}{A \times N}$

Where $W$ is the weight given to each factor by the respondents and ranges from 1 to $5 ; A$ is the highest weight $=5$; and $N$ - the total number of respondents.

\section{Regulations, Legislation and Policies}

As the most significant constraint, government regulations, legislation and policies were seen to be the main barrier to implementing good H\&S practice. At the procurement level, poor safety performance can be explained by contractor selection criteria based on principles of lowest cost, which was ranked as the highest sub-constraint to achieving better

Alkilani, S Z et al (2013) 'Issues of construction health and safety in developing countries: a case of Jordan', Australasian Journal of Construction Economics and Building, 13 (3) 141-156 
H\&S practices. Results show that both the tendering body and contractor fail to properly consider H\&S costs. In addition, the current procurement methods primarily used in Jordan, and in particular in the public sector, fail to clearly outline each party's responsibilities. The absence of a unified set of regulations adversely affects the enforcement of $\mathrm{H} \& \mathrm{~S}$ on the job site and was ranked as the second most significant sub-constraint. There are no specific regulations, standards, and laws pertaining to the site conditions of construction projects. There are also no established construction safety standards or manuals provided by the MPWH or the Ministry of Labour. In cases where construction projects are sponsored by international agencies or undertaken by foreign contractors they are governed by their own country or International Contractors' H\&S Standards. However, international standards are not necessarily applicable to the work conditions and environment of Jordan since methods of practice in advanced and industrial countries can differ widely from those used in Jordan.

The interview results also show that there is a lack of national H\&S indicators and measures, as well as a lack of official safety data and records of construction accidents on site, making $\mathrm{H} \& \mathrm{~S}$ one of the last issues to be considered by contractors and clients. Another significant challenge identified was the lack of compliance and certification standards suitable for Jordan's construction environment. Participants noted the absence of benchmarking processes that encompass apposite KPIs.

While innovation is regarded as an engine of economic growth, and a driver for poverty alleviation in developing countries (UNESCO 2010), a significant finding from this study shows that a lack of innovation, and research and development (R\&D) is ranked as the least significant barrier to better H\&S practices in Jordan. This confirms the fact that in developing countries little attention can be paid to R\&D by SMEs. The SME contractor participants claimed that due to low profit margins and lack of government funding and tax incentives, their firms could not invest in R\&D. Whilst this factor was ranked lowest of all seven barriers, it is one of the most crucial for improving construction H\&S performance. Further, in a previous study conducted by (Alkilani et al. 2012b) it was found that there is a low capacity amongst Jordanian SME contractors to adopt new innovations, such as new information technologies, was perceived by contractors as a key contributing factor in the shortfalls in productivity.

\section{Management Commitment and Involvement}

Overall, the respondents ranked 'Management Commitment and Involvement' as the second most significant barrier to implementing good H\&S practice, with an RII of 0.76 . Respondents revealed that the senior management levels of all the construction firms interviewed were ultimately responsible for increases in accident rates due to their lack of willingness to allocate resources to the implementation of the necessary $\mathrm{H} \& \mathrm{~S}$ procedures onsite. The results show that clients and consultants stressed the importance of H\&S issues before work commences, but as the work progresses each stakeholder's concern to meet deadlines takes priority and less attention is paid to safety.

Compounding this issue is the fact that the construction industry in Jordan is dominated by SMEs, which are characterized by combined owner-manager leadership arrangements and are typically family-run enterprises. In such firms, owner-managers were found to act as gatekeepers in the allocation of resources, where more often they were not willing to prioritize the application and monitoring of H\&S procedures onsite because of a focus on businesses growth - where profits where reinvested into areas that increased construction capacity and competitive advantage. The attitudes of the SME contractors interviewed also differed in relation to those of larger firms. SMEs considered H\&S as a waste of resources and tended to have a lack of awareness of the effectiveness of safety prevention programs in reducing costs and increasing productivity. The results also reflect the fact that a considerable number of workers were not trained to recognize and avoid the risks

Alkilani, S Z et al (2013) 'Issues of construction health and safety in developing countries: a case of Jordan', Australasian Journal of Construction Economics and Building, 13 (3) 141-156 
associated with their tasks. This leaves those workers more susceptible to potential accidents.

\section{Worker Awareness}

'Worker awareness' was ranked as the third most significant barrier to implementing good $\mathrm{H} \& \mathrm{~S}$ practice in Jordan. This is in contrast to findings of previous research relating to H\&S in developing countries, which highlights the adverse effects of using unskilled foreign labor on construction industry H\&S performance. In a study by Kartam et al. (2000), it was shown that the extensive use of unskilled foreign labor in developing countries was one of the greatest threats to maintaining a safer construction sites. Despite this lower ranking overall, the RII values shown in for the three sub-constraints (used to define worker awareness) reveal that participants ranked them as being of similar significance resulting in a lower variance and range between these rankings $\left(\sigma^{2}=0.0018\right.$ and $\left.R=0.09\right)$ when compared to the other two groups of sub-constraints ( $\sigma^{2}=0.0202$ and $R=0.42$, and $\sigma^{2}=0.0045$ and $R=0.19$ respectively). The majority of respondents agreed that workers were reluctant, or neglected, to wear PPE. With the absence of onsite safety equipment and its lax enforcement an obvious lack of commitment across all levels of the construction company was identified as a major constraint to the improvement of construction site safety.

The high level of employment of foreign labor has long been a defining characteristic of the Jordanian construction industry. Different cultures, traditions and attitudes to work impact on human relations, in particular in relation to differences in work habits and communication. The majority of construction workers in Jordan are unskilled, untrained, and inexperienced. Foreign workers often come from poor communities and are willing to work in inferior working conditions. The workers are emotionally vulnerable and sometimes preoccupied with personal economic problems since most of them are working in unsecured conditions and their employment is not tied to an employment sponsorship agreement. All of these conditions can affect the concentration and attention of the worker and may contribute to mistakes.

\section{Discussion: Summary of Problems and Possible Solutions}

To improve H\&S performance in the Jordanian construction industry a number of programmes can be developed, adapted from existing initiatives undertaken in other countries and implemented in a way which is sensitive to the contextual variables of Jordan's construction sector. Research on other developing countries has placed similar deficiencies in H\&S performance under the spotlight (Farooqui et al. 2008, Koehn et al. 1995, Kartam et al. 2000, Jill and John 2010). Academia and industry research initiatives (Gibb and Bust 2006, Farooqui et al. 2008, Jill and John 2010, Alkilani et al. 2012a) propose solutions and recommendations on a range of $\mathrm{H} \& \mathrm{~S}$ challenges facing the construction industries of developed and developing countries. These have mainly focused on programs that are either led by government or industry. With the objective of highlighting the importance of joint initiatives between government and industry the authors propose that the existing proposed solutions be extended and adapted.

\section{Joint Government-Industry led Initiatives}

In order to realise tangible results in terms of improvement in H\&S performance in construction, the formation of a hybrid agency is essential. By bringing Government and industry bodies together a number of important initiatives can be achieved including: (1) revision of H\&S codes and standards, (2) reforms to current procurement processes, and (3) promotion of H\&S best-practice and culture, as well as the development and implementation of training and education programs for workers.

- Revising H\&S Codes and Standards: The revision and development of new regulations that are relevant and up-to-date is essential. In undertaking such major

Alkilani, S Z et al (2013) 'Issues of construction health and safety in developing countries: a case of Jordan', Australasian Journal of Construction Economics and Building, 13 (3) 141-156 
reform, the MPWH together with the Ministry of Labour must work to draft new H\&S regulations for the administration of safety. . A more comprehensive set of requirements that target the specific conditions of the construction industry is required so as to take into consideration the environmental, human, technological and social aspects,

- Procurement Reform: Current tender applications and contractor selection processes should be improved such that H\&S is more clearly integrated. It is essential that safety responsibilities be specified in the contract as well as ways in which H\&S measures are implemented and monitored onsite. Contractual specifications should also establish guidelines in order to prevent risk and identify hazards,

- Promotion of best-practice and development of H\&S culture: Lack of best practice and culture surrounding H\&S is related directly to the uncertainty, ambiguity and lack of awareness of H\&S in the construction industry. H\&S education is therefore critical to increasing the industry's performance and to fostering more positive attitudes towards $\mathrm{H} \& \mathrm{~S}$ issues.

To support a joint initiative a number of government-led and industry led programs could also be implemented.

\section{Government-led Initiatives}

Government-led initiatives and programs include (1) the introduction of incentives, (2) the adoption of H\&S indicators, and (3) provision of leadership in procurement. These initiatives should however take into consideration the conditions of Jordan's construction industry in the following ways.

- Introduction of incentives: Incentives that seek to improve H\&S, e.g., via the use of appropriate tax incentives and penalties that consider the financial situation of all five grades of construction firm.

- Adoption of H\&S Indicators: Government can assist the construction industry reconsider the importance of H\&S in order to improve the industry's image (Ofori 2001) . The staggered introduction of a set of indicators to track the Jordanian construction industry's safety record would facilitate this objective. These could include:

a. Construction accidents frequency rate,

b. Severity rate of accidents,

c. Injuries (\# of persons suffering minor injury, permanent disability, fatality), and

d. Enforcement action for non-compliance such as fines, suspensions or deregistration.

- Leadership in Procurement: As a minimum requirement, the MPWH Government Tendering Department contract specifications for public projects should contain specific guidelines to control all anticipated hazards by:

a. Identifying persons responsible for overseeing contractor's performance,

b. Requiring contractors to prepare and submit an acceptable project hazard prevention plan that defines supervisory and employee safety training,

c. Identifying specific published safety standards and hazard prevention requirements, and

d. Listing qualifying requirements for eligible contractors to ensure bidders are restricted to those whose past performance demonstrates key H\&S competencies.

\section{Industry-led Initiatives}

Industry-led initiatives and programs include (1) risk and role sharing, (2) increasing available knowledge and developing H\&S resources, (3) organisation-based KPIs for H\&S, (4) increasing the involvement and accountability of senior management in $\mathrm{H} \& \mathrm{~S}$, and (5)

Alkilani, S Z et al (2013) 'Issues of construction health and safety in developing countries: a case of Jordan', Australasian Journal of Construction Economics and Building, 13 (3) 141-156 
increasing efforts to adopt new information technologies. Like government-led programs each initiative must take the conditions surrounding Jordan's construction industry into consideration in their development and implementation.

- Risk and role sharing: Developing partnerships between those involved in concept, design, construction planning, construction work, and maintenance. Jordanian developers and clients in particular should be encouraged to play a greater role in driving H\&S by defining safety objectives in project scoping documents, selecting safe contractor and participating in onsite safety management,

- Increasing available knowledge and developing H\&S resources: Launching H\&S information banks and databases so as to make publicly accessible appropriate statistical information, accident records, and accident prevention methods,

- Organisation-based KPIs for H\&S: Performance indicators that focusing on H\&S practices that are sensitive to the context of Jordan should be established and agreed to by project stakeholders. National KPIs concerning H\&S are critical to an industry-led solution, and should be be utilised by all five grades of construction firms,

- Increasing involvement of senior management: this requires giving safety a higher priority in company meeting, involvement by senior management in safety activities, open communication channels between workers and management on safety issues, and an emphasis on workers training and education programs,

- Increasing efforts to adopt new information technologies: Increasing the use of computer-based H\&S applications and technologies.

\section{Conclusion}

The findings from the investigation provide a broad perspective of the legal, institutional, business and cultural frameworks shaping H\&S management of indigenous construction across both the public and private sectors in Jordan. The study reveals that H\&S management and measurement in Jordan is still in its infancy. There is a lack of government commitment exemplified by the inability to enforce regulations, policies and legislation which limits the operational efficiency of government departments responsible for OHS management and hinders the development of good H\&S practice. The study highlights several key constraints that challenge the development of good H\&S practice among construction contractors. Whilst the findings stemming from this study and the possible solutions recommended here focus on the Jordanian construction industry, the literature and anecdotal evidence obtained by interviewees suggests that the situation is not significantly different in other developing countries.

\section{Acknowledgments}

Special thanks to safety personnel at Ministry of Labour, Ministry of public works and Housing, and construction contractors who contributed to this research.

\section{References}

Abdelhamid, T. S. and Everett, J. G. 2000. Identifying root causes of construction accidents. Journal of Construction Engineering \& Management, 126 (1), 52.

Agyem-Bediako, S. F., 2007. Management commitment to safety among multinational construction companies in developing countries: A case of Ghana. 3260116 (Sc.D.). University of Massachusetts Lowell.

Alkilani, S., Jupp, J. and Sawhney, A., 2012a. Promoting Health and Safety in Construction in Developing Countries: A Case of Jordan. CIB W099 International Conference on Modeling \& Building Health \& Safety. Singapore.

Alkilani, S., Jupp, J. and Sawhney, A., 2012b. Readying a Developing Economy for National Performance Measurement and Benchmarking: A Case Study of the Jordanian Construction

Alkilani, S Z et al (2013) 'Issues of construction health and safety in developing countries: a case of Jordan', Australasian Journal of Construction Economics and Building, 13 (3) 141-156 
Industry. Visions for the future of housing: Mega cities. Turkey: IIAHS World Congress on Housing.

Bowen, P., Tookey, J. and Hardcastle, C., 2002. Construction Procurement and Management in the UK \& South Africa. 10th Symposium Construction Innovation and Global Competitiveness. CRC Press, 476-497.

Charles, C. 2007. Construction Safety anf Health Factors at the Industry Level: The Case of Singapore. Journal of Construction in Developing Counreies, 12 (2).

Charles, M., Pillay, J. and Ryan, R., 2007. Guide to Best Practice for Safer Construction: Literature Review from Concept to Completion. Australia: Cooperative Research Centre for Construction Innovation.

Chi, C.-F., Chang, T.-C. and Ting, H.-I. 2005. Accident Patterns and Prevention Measures for Fatal Occupational Falls in the Construction Industry. Applied Ergonomics, 36 (4), 391400.

Chileshe, N. and Dzisi, E. 2012. Benefts and Barriers of Construction Health and Safety Management (HSM): Perception of Practioners within Design Organisations. HJournal of Engineering, Design and Technology, 10 (2).

Chiocha, C., Smallwood, J. and Emuze, F. 2011. Health and Safety in the Malawian Construction Industry. Acta Structilia, 18 (1).

Colin, F. 1999. Benchmarking Health and Safety Performance Through Company Safety Competitions. Benchmarking: An International Journal, 6 (4), 325-337.

DOL, 2010. A principal's guide to contracting to meet the Health and Safety in Employment Act 1992. NZ.: Department of Labour.

EASHW, 2013. The European Agency for Safety and Health at Work (EU-OSHA) [online]. EU. Member States. Available from: https://osha.europa.eu/en/about.

El-Mashaleh, M., et al. 2010. Safety Management in the Jordanian Construction Industry. Journal of Civil Engineering, 4 (1).

Fang, D. P., Huang, X. Y. and Hinze, J. 2004. Benchmarking Studies on Construction Safety Management in China. Journal of Construction Engineering \& Management, 130 (3), 424432.

Farooqui, R., Arif, F. and Rafeeqi, S. F., Safety Performance in Construction Industry of Pakistan. ed. First International Conference on Construction in Developing Countries, 2008 Karachi, Pakistan.

Gibb, A. and Bust, P., 2006. Construction healtha and safety in developing countries. UK: European Construction Institute.

Hamalainen, P. i., Takala, J. and Leena Saarela, K. 2007. Global Estimates of Occupational Accidents. Safety Science, 44 (16), 137-156.

Hinze, J., Coble, R. J. and Haupt, T. C., 2000. The Management of Construction Safety and Health. Rotterdam ; Brookfield, VT: A.A. Balkema.

Hinze, J. and Wilson, G. 2000. Moving Toward A Zero Injury Objective. Journal of Construction Engineering \& Management, 126 (5), 399.

Idoro, G. 2011. Comparing Occupatioal Health and Safety (OHS) Management Efforts and Ferformance of Nigerian Construction Contractors Journal of Construction in Developing Counreies, 16 (2), 151-173.

ILO, 1992. Health and safety in construction, an ILO code of practice. Geneva, International Labor Office, report no, 08.10.1.

ILO., 2010. The Role of Worker Representation and Consultation in Managing Health and Safety in the Construction Industry. Geneva.

Alkilani, S Z et al (2013) 'Issues of construction health and safety in developing countries: a case of Jordan', Australasian Journal of Construction Economics and Building, 13 (3) 141-156 
Jannadi, O. A. and Bu-Khamsin, M. S. 2002. Safety factors considered by industrial contractors in Saudi Arabia. Building and Environment, 37 (5), 539-547.

Jaselskis, E. J., Anderson, S. D. and Russell, J. S. 1996. Strategies for Achieving Excellence in Construction Safety Performance. Journal of Construction Engineering \& Management, $122(1), 61$.

JCCA, 2012. The Current Status of Construction Sector in Jordan. Amman: Jordanian Construction Contractors Association

JDOS, 2010. Jordanian Construction Sector Statistical Survey 2008-2009. Amman: Jordanian Department of Statistics.

JEDCO, 2011. SME Development in Jordan [online]. Jordan: Jordan Enterprise Development Corporation. Available from: http://worldsmeexpo.hktdc.com/pdf/2011/SeminarRoom C/Dec 3/1630 1800 24/2 AAlAhmad.pdf.

Jill, W. and John, H., 2010. Promoting Construction Health and Safety through Procurement: $A$ briefing note for developing countries. Institution of Civil Engineers

John, L. and Anthony, M. 2001. Measuring the occupational health and safety performance of construction companies in Australia. Facilities, 19 (3), 131-139.

Kartam, N. A., Flood, I. and Koushki, P. 2000. Construction Safety in Kuwait: Issues, Procedures, Problems, and Recommendations. Safety Science, 36 (3), 163-184.

Kheni, N., Gibb, A. and Dainty, A., The Management of Construction Site Health and Safety by Small and Medium-Sized Construction Businesses in Developing Countries: A Ghana Case Study. ed. 22nd Annual ARCOM Conference, 2006 Birmingham. UK, 295-304.

Koehn, E. E., Kothari, R. K. and Pan, C.-S. 1995. Safety in Developing Countries: Professional and Bureaucratic Problems. Journal of Construction Engineering \& Management, 121 (3), 261.

Kometa, S. T., Olomolaiye, P. O. and Harris, F. C. 1994. Attributes of UK construction clients influencing project consultants' performance. Construction Management \& Economics, 12 (5), 433.

Konkolewsky, H.-H., 2004. Actions to Improve Safety and health in Construction. Magazine of the European agency fro safety and Health at work. Belgium.

Larcher, P. and Sohail, M., 1999. Review of safety in construction and operation for the WS\&S secto: part 1. London. UK.: London school of hygiene and tropicla medicine, UK.

Levitt, R. E. 1976. Reducing Construction Accidents-Top management's Role. Journal of the constrcution Division, 102 (3), 465-478.

MOL, 2010. Anual report. [online]. Amman. Jordan: Ministry of Labour. Available from: http://www.mol.gov.jo/default.aspx?tabid=175.

Murie, F. 2007. Building Safety-an International Perspective. International Journal of Occupational and Environmental Health, 13 (1), 5-11.

NEBOSH, 2013. The National Examination Board in Occupational Safety and Health [online]. UK. Available from: http://www.nebosh.org.uk/About Nebosh/.

$\mathrm{NIOSH}$, 2012. The National Institute for Occupational Safety and Health [online]. Washington, D.C. US. Available from: http://www.cdc.gov/niosh/about.html.

Ofori, G. 2001. Indicators for measuring construction industry development in developing countries. Building Research \& Information, 29 (1), 40 - 50.

Ofori, G., 2011. New perspectives on construction in developing countries. Abingdon, Oxon ; New York: Spon Press.

Alkilani, S Z et al (2013) 'Issues of construction health and safety in developing countries: a case of Jordan', Australasian Journal of Construction Economics and Building, 13 (3) 141-156 
Paivi, H., Jukka, T. and leena, S. K. 2006. Global etimates of occupational accidents. Safety Science, 44, 37-156.

Petrovoc-Lazarevic, S. and Perry, M., 2004. Occupational Health and Safety Shortcomings in the Australian Construction Industry.

Scotney, V., 2000. Development of Health and Safety Perfromance Measurement Tool. UK: Health and Safety Excutive, report no, 309/2000.

Teo, E. A. L., Haupt, T. and Feng, Y., 2008. Construction Health and Safet Performance in Developing and Developed Countries: A Parallel Study in South Africa and Singapore. CIB W99 International Conference. Gainesville, Florida, 485-499.

Toole, T. M. 2002. Construction Site Safety Roles. Journal of Construction Engineering \& Management, 128 (3), 203.

UNESCO, 2010. Measuring R\&D: Challenges Faced by Developing Countries.: UNESCO Institute for Statistics.

Weil, D. 2001. Assessing OSHA Performance: New Evidence from the Construction Industry. Journal of Policy Analysis \& Management, 20 (4), 651-674. 